\author{
Abstracta Iranica \\ Abstracta Iranica Revue bibliographique pour le domaine irano-aryen \\ Volume 37-38-39 | 2018 \\ Comptes rendus des publications de 2014-2016
}

\title{
Winfried Held, Deniz Kaplan. "The Residence of a Persian Satrap in Meydancıkkale, Cilicia"
}

\section{Astrid Nunn}

\section{(2) OpenEdition}

\section{Journals}

Édition électronique

URL : http://journals.openedition.org/abstractairanica/45498

DOI : 10.4000/abstractairanica.45498

ISBN : 1961-960X

ISSN : 1961-960X

Éditeur :

CNRS (UMR 7528 Mondes iraniens et indiens), Éditions de l'IFRI

Référence électronique

Astrid Nunn, « Winfried Held, Deniz Kaplan. "The Residence of a Persian Satrap in Meydancıkkale, Cilicia" », Abstracta Iranica [En ligne], Volume 37-38-39 | 2018, document 46, mis en ligne le 30 décembre 2018, consulté le 26 septembre 2020. URL : http://journals.openedition.org/ abstractairanica/45498 ; DOI : https://doi.org/10.4000/abstractairanica.45498

Ce document a été généré automatiquement le 26 septembre 2020

Tous droits réservés 


\title{
Winfried Held, Deniz Kaplan. “The Residence of a Persian Satrap in Meydancıkkale, Cilicia"
}

\author{
Astrid Nunn
}

\section{RÉFÉRENCE}

Winfried Held, Deniz Kaplan. "The Residence of a Persian Satrap in Meydancikkale, Cilicia" in Robert Rollinger, Erik van Dongen (eds.). Mesopotamia in the Ancient World. Impact, Continuities, Parallels. Proceedings of the Seventh Symposium of the Melammu Project Held in Obergurgl, Austria, November 4-8, 2013. Münster: Ugarit-Verlag, 2015, p. 175-191.

1 Le site de Meydancıkkale est caractérisé par des remparts imposants construits à l'époque achéménide. Dans la partie sud du site se situe le «Bâtiment A » fouillé de 1971 à 1980. Il est rectangulaire et mesure 19.50 x $26.50 \mathrm{~m}$. Ses fondations remontent au Vème s. mais la datation de ses structures principales - hellénistiques selon les fouilleurs - est controversée. Le plan reste sans parallèle ce qui rend l'identification de sa fonction sujette à débat. Deux reliefs achéménides qui montrent des Perses portant une coupe ont été découverts à proximité. Pour trancher la question de la datation, les A. réexaminent les bases de colonnes trouvées dans le site et, tout en réorganisant légèrement le plan du Bâtiment $A$. Ils optent résolument pour une datation achéménide. Peut-être même s'agissait-il d'une résidence de satrape. 


\section{AUTEURS}

\section{ASTRID NUNN}

Université de Munich 